Volume 12

Issue 2 June

Article 8

May 1985

\title{
Students' Views on the Future of Social Work
}

Donald E. Maypole

University of Northern lowa

James G. McCullagh

University of Northern lowa

Follow this and additional works at: https://scholarworks.wmich.edu/jssw

Part of the Social Work Commons

\section{Recommended Citation}

Maypole, Donald E. and McCullagh, James G. (1985) "Students' Views on the Future of Social Work," The Journal of Sociology \& Social Welfare: Vol. 12 : Iss. 2 , Article 8.

Available at: https://scholarworks.wmich.edu/jssw/vol12/iss2/8

This Article is brought to you by the Western Michigan University School of Social Work. For more information, please contactwmu-scholarworks@wmich.edu.

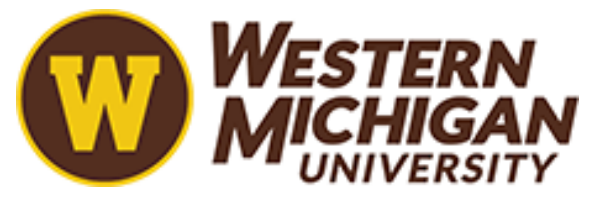


STUDENTS' VIEWS ON THE FUTURE OF SOCIAL WORK

\author{
Donald E. Maypole, Ph.D., ACSW \\ and \\ James G. McCul lagh, Ed.D., ACSW \\ Associate Professors \\ Department of Social Work \\ University of Northern Iowa \\ Cedar Falls, Iowa 50614
}

\begin{abstract}
The need for the social work profession to understand the meaning of socio-economic and political trends has never been more important than at present. However, the application of future projection technology has lagged behind this need. The authors $s$ tudied the views of students from eighteen universities and colleges on present socioeconomic trends, as represented by future specific scenarios. The implications of the future scenarios are discussed in relation to social justice, soclal work practice and education.
\end{abstract}

Social workers are becoming increasingly aware of the interrelatedness of socio-economic-demographic-poIitical forces as they impact our profession and the services delivered to our clients. The deteriorating economy and physical environment, rapid technological change, loosening of family ties, political polarization, exploding social problems and increasingly hostile geopolitical international environment are accelerating structural changes in the profession, practice and edu-

The project was funded by a grant from the Graduate college of the University of Northern Iowa. 
cation. This study examines the potential impact of these changes on future social work practice and education.

\section{STUDY PURPOSE}

The purpose of this study is to apply contemporary technology to discussions on futures, by ascertaining the views of one group of social workers (social work undergraduate junfor and seniors and graduate students), in regard to the likely scenario to occur in the period of 1985 to 1990, and the scenarios' implications for social justice, social work practice and education. The assumptions in selecting the students were that they are aware of social change forces and are concerned about social justice and socio-economic impacts on the profession's education and practice. Also, as the students of today, they' 11 be the practitioners of tomorrow and will participate in shaping social work's future. The research questions were designed to determine:

1. The most likely scenario for the period 1985-1990.

2. For the chosen scenarios-

a. The degree of soctal justice for each socio-economic class.

b. The implications for social work practice and education.

3. The relationships between the respondents' demographic characteristics and their chosen scenario.

A discussion of forecasting technology in social work is followed by the study's methodology, findings and implications for practice and education.

\section{FORECASTING IN SOCIAL WORK}

In response to social changes, a number of writers have attempted to assess their impacts on social work practice and education. Brief summaries of selected writings follow. In 1966, John W. Gardner (Secretary 
of the Federal Department of Health, Education, and Welfare, at that time) predicted that soc1al work would play a considerably expanded role in the future (Gardner, 1966). He asserted that in the 1990's the schools of social work would evolve into social work education centers. These centers would play pivotal roles in the development and implementation of social policies in the United States.

Kendall (1967) questioned the value of the generic approach to curriculum bullding and asserted that more focus must be applied to the teaching of fundamental knowledge of social and behavioral sciences at the undergraduate level. There were three challenges in social work education, those of increasing quality, quantity, and varieties of educational output, according to Pins. Social workers with various levels of education were needed, such as social service aid, bachelor's level, master's level and the doctorate level (PIns, 1967).

David (1967) described the trend toward specialization of knowledge, skills, functions and task in social work. He asserted that there was a need to enhance the quality of social work education, including the teaching of "future-mindedness." Lowy (1968) reviewed the need for social work education at four levels - MSW, BSW, technical, and inservice training for existing practitioners--and argued that social workers must understand research.

The rapid changes in social work education were reflections of the rapid changes in the American society, according to Reichert (1970). He observed that new disciplines were competing with social work in the human services field and that there was a movement from emphasizing individual adjustment to the environment to creating social opportunities and economic provisions for people to resolve their difficulties.

Briar (1974) noted the increasing pessimism and feelings of frustration in relation to solving social problems in the United States. The United States was beginning a period of economic decline. He believed that direct services would continue to be the mainstay 
of the profession, that the incursions on social work "turf" will continue and that there was a continual need for administrative training. Boehn (1976) discussed the changes in American society and their Impact on social work and social work education, such as the importance of experiential learning, continuing education and values.

Social workers could expect Increased opportun1ties in four areas - social policy and planning, efficlency and accountability, local inttiative, and social advocacy, according to Rothman (1979). Washington (1978) advocated that social work education play a leadership role in the profession. He suggested that students be taught skills in developing citizen participation, community leadership and social policy analysis and advocacy. He further asserted that social work education should become more interdisciplinary and that students should be trained to become administrators and advocates for social work values.

A 1979 conference - "Issues in Baccalaureate Social Work Education and Practice as We Look to the 1980s" addressed a number of issues in undergraduate curriculum content. In 1 ts report, Cohen stated that the undergraduate curriculum should provide at least minimal preparation for management and working within organizations (Issues in Baccalaureate Social Work Education, 1979).

The 1982 Council on Social Work Education Annual Program Meeting theme was "The Future of Social Work Education: The Next Eight Years." The topics included ideas on administration, budgeting, the job market, maintaining educational quality, evaluating educational outcomes, utilizing expertise from other disciplines, and preserving individual freedom (Social Work Education Reporter, 1982). Further emphasis on the need to increase student education in community organization was shown in a recent CSWE House of Delegates Meeting, in which it was suggested that CSWE encourage greater commitment on the part of accredited programs to teaching social action skills (CSWE, 1982).

While the above writers and presenters were wellinformed individuals, their speculations fall into the 
futures prediction category of "genius forecasting." Jones (1980) has pointed out that this intultive method is based on insight and luck and that more formalized methods are increasingly being used. Social work writers are just beginning to discuss the new techniques. For example, Meinert (1973) suggests a framework for forecasting methodologies: extrapolation, Delphi approach, simulations, and scenario speculation. Abels (1975) proposes the use of scenarios for future projections. He argues that more emphasis is needed on the implications of new technology on the profession. He used the Delphi method for determining dates for certain events, e.g., poverty reduction and control of deviant behavior.

Washington (1978) advocates a five part framework for futures predictions. The first is to make speculative fudgements based on the past. An alternative technique is to base future projections on present social work roles. His third suggestion is to forecast the social-technical structure of society and to factor out the human needs to which social work can relate. The fourth technique is to base speculations on federal legislation and the $f$ ifth is to use behavioral science knowledge for projections on the relationships between people and their environment. Dolgoff and Feldstein (1984) propose a wellconceptualized taxonomy for futures forecasting: trend curves, correlation methods, causal models, scenarios, Delphi technique and computer simulation.

In 1978, NASW created a Professional Futures Commission to begin systematically studying the future. Recently, Beck (1981), Chair of the Commission, described four possible scenarios of the future: "The American Dream," "The Unfulfilled Dream," "Sweet" Transformationalism, and "Sour" Transformationalism. The Commission's work, as reflected in Beck's writings and other Comission documents, is likely to result in discussion among social work practitioners, educators, and students. However, except for the use of the Delphi technique, none of the existing social work literature concerning the future has reflected empirical attempts to secure the views of a broad-based group of social workers. This exploratory-descriptive study uses 
"future scenarios" to partially fill in this gap. METHODOLOGY

Design/Sample

A cross-sectional survey was conducted in the spring of 1982 of undergraduate social work juniors and sentors and $M S W$ students in 18 universities and colleges throughout the United States.1 Approximately one-third of the 539 students who participated in the study were enrolled in MSW programs and the remainder were enrolled in BSW programs. A nonprobability sample was used. Most of the particlpating schools are in the Midwest and South. The researchers requested colleagues to administer the questionnalies to eligible students in their classes. For the $13 \mathrm{BSW}$ programs, the response rate for the juniors and sentors who received the questionnalre varied from 84 to 100 percent. The student response rate in the five MSW and BSW/MSW programs ranged from 92 to 98 percent. No atcempt was made to control for class domain (policy or practice), since it was believed that concerns about the future transcended the particular classes.

Data Collection Instrument

The questionnaire, which included a summary description of the Commission's four proposed scenarios, was designed to gather subjects' views about the scenarto likely to occur in 1985-1990; degree of social justice for lower, middle, and upper classes; implications of the chosen scenario for social work practice and education; and demographic and academic information. Classroom Instructors read the instructions, distributed the questionnaires and collected them. Students read the following abstracts of the four scenarios, prior to answering the survey questions: 
Scenario 非 (THE AMERICAN DREAM): The U.S. will have a thriving economy based on computer technology. Government monitors the use of energy and business activities. Social services/income support are mostly directed to the middle-aged and elderly who can't adjust to the new affluent social system. There is a negative income tax. Government is run like a corporation. Education is enormously important and the key to job success. Social and health systems are efficlent and effective. Social work emphasizes specialization, certification and legal regulation.

Scenario \#2 (THE UNFULFILLED DREAM): Environmental problems are rife and technology does not solve them. Health and social problems abound. Terrorism is rampant. Government control foremost. Unemployment is high. Racism persists. Unions are strong. Government offers a host of social provislons and services to seek political stability. Rightest politics is ascendant. Corporations become more important in political affairs. Social workers must choose between helping the poor or the mainstream of Americans.

Scenario \#3 (SWEET TRANSFORMATIONALISM): A Peoples's Party, with a liberal philosophy, comes to power. The economy is rebuilt, unemployment is decreased, tax breaks for business are reduced and tax incentives are of fered to labor-intensive industries. Community development corporations pool resources to organize food production, employment and other essential local activities. They enter health and social services and emphasize self-help. The bureaucracy is abolished and these decentralized groups assume their functions. There are few jobs for trained social workers; the profession disappears. Social workers must find jobs in the business sector and become unpaid volunteers in the development groups. 
Scenar10 \#4 (SOUR TRANSFORMATIONALISM): Terrorists take command of the worldwide energy resources. There may be large-scale war. Centrallzed power and the bureaucracy deteriorates. People turn to alternative life$s$ tyles. The standard of living deteriorates. Social workers pitch in to distribute food and shelter for the increasingly needy population. They work for low or no salaries to organize people into emerging, local commual groups. Within the power vacuum, a reactionary force emerges which represses dissent, pays no need to the human needs of the population and operates for 1 ts own benefit. There are no jobs for social workers and the profession dies (Beck, 1981).

\section{FINDINGS}

\section{Study Sample}

The majority of the 359 BSW student respondents were white $(86 \%)$, female $(85 \%)$, and single $(80 \%)$, with a median age of 21.8 . Their mean university grade polnt average (GPA) was 3.07. Political orientations included liberals $(39 \%)$, moderates ( $30 \%)$, conservatives $(8 \%)$, and radicals $(5 \%)$. No one indicated "ultraconservative" and 18 percent responded "no preference." The $180 \mathrm{MSW}$ students were mostly female (74\%), white (92\%) and single $(55 \%)$, with a median age of 28.8 . Their mean university GPA was 3.64. The largest part of this group described 1 tself as liberal ( $42 \%$ ). Thirty-five percent identified themselves as moderates, 12 percent conservative and 5 percent radical. Only 5 percent indicated no preference.

National demographic data on baccalaureate and master's programs in social work suggest that the sample ratio of males to females is comparable, but the percent of minority students is less than that found in some current BSW and MSW programs (Rubin, 1982).

\section{Scenario Chosen}

After reading summary descriptions of the scenarlos, subjects were asked, "Which one scenario do you 
believe is the most likely to occur in the period 19851990 ?" The vast majorlty $(80 \%)$ of the sample chose "The Unfulfilled Dream" as being the most representative of the short-term socio-economic political future for the United States (Table 1). Only twelve percent chose the "American Dream" and only a few chose the "Transformationalist" scenarios. A comparison with the results of a similar survey performed by the Iowa NASW Chapter on Its membership in 1982, revealed marked similarity in cholce of scenario to the finding presented herein, thereby providing an indication of generalizability.

The percentage difference between choice of "The Unfulfilled Dream" and the other three scenarios is sufficient to indicate that the majority of respondents anticipate no major breaks in current national policy and societal attitudes. Further analysis revealed that scenario cholce was not related to marital status, ethnicity, or gender, but was related to self-reported political orientation. Moderates and liberals tended to choose the pessimistic "Unfulfilled Dream" scenario significantly more than conservatives and respondents who Indicated no preference. These groups tended to choose the more optimistic "American Dream." A $2 \times 4$ chi-square analysis failed to ascertain any statistically significant difference in choice of scenario between BSW and MSW students.

Social Justice

To determine perceptions of social justice, subjects were asked, "For your chosen scenarlo, what will be the degree of social justice for lower, middle and upper class Americans?" An Inspection of the degree of social justice for the three American socio-economic classes reveals a perception of discrimination, as shown In Table 2. Regardless of the scenario chosen, the ordinal relationship between the classes holds - the upper class will recelve the most social justice and the lower class will recelve the least. Clearly, the existing inequities in social stratification are expected to continue. In addition, the study of the mean justice scores for the lower class shows a great variation between scenarios. "The American Dream" and "Sweet Transformationalism" (as optimistic views) indicate the 
Table 1

Scenario Chosen and Political Orientation

Scenario Chosen

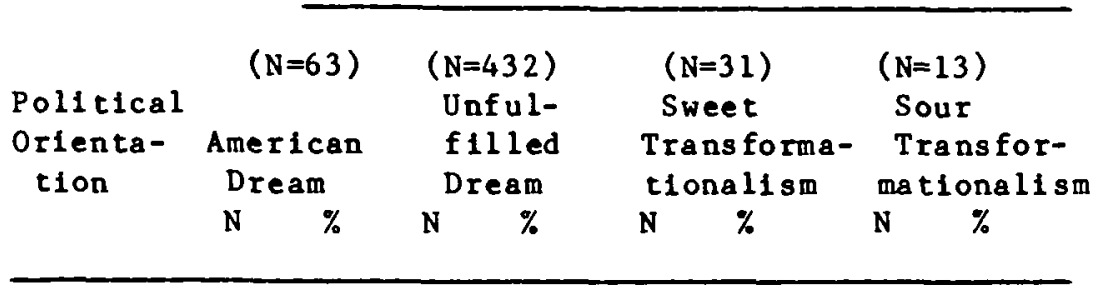

Conser-

$\begin{array}{lllllllll}\text { vative } & 8 & (16 \%) & 36 & (74 \%) & 3 & (6 \%) & 2 & (4 \%)\end{array}$

Moderate $29 \quad(17 \%) 123 \quad(71 \%) 14 \quad(8 \%) \quad 6 \quad(4 \%)$

$\begin{array}{llllllll}\text { Liberal } & 13 & (6 \%) & 187 & (88 \%) & 10 & (5 \%) & 2\end{array}$

$\begin{array}{llllllll}\text { Radical } & 1 & (4 \%) & 22 & (88 \%) & 0 & (0 \%) & 2\end{array}$

$\begin{array}{lllllll}\text { No Pref- } 11 & (15 \%) & 56 & (78 \%) & 4 & (6 \%) & 1\end{array}$

erence

$\left(x^{2}=26.5, p<0.009, d f=12\right)$ 
Table 2

Mean Degree of Social Justice By Scenario and Class

Class

$\begin{array}{lll}\text { Scenario Upper Middle Lower } & \end{array}$

\begin{tabular}{|c|c|c|c|}
\hline The American Dream & 5.07 & 4.08 & 3.18 \\
\hline The Unfulfilled Dream & 4.10 & 3.12 & 1.93 \\
\hline $\begin{array}{c}\text { Sweet Transforma- } \\
\text { tionalism }\end{array}$ & 4.23 & 3.68 & 3.17 \\
\hline $\begin{array}{c}\text { S our Transforma- } \\
\text { tionalism }\end{array}$ & 5.15 & 3.15 & 1.46 \\
\hline
\end{tabular}

Note: Six point scale with 1 being none and 6 being greatest degree of social justice. 
most social justice for the lower class and "The Unfulfilled Dream" and "Sour Transformationalism" show the least.

According to the students, in terms of social justice, the future of the lower socio-economic class appears to be quite bleak.

\section{Implications for Social Work Practice and Education}

To ascertain implications for social work practice and education, students were asked the following: "Taking into account limited resources, what are the implications of your chosen scenario for social work practitioners and social work education in the period 1985-1990?" Respondents then rated the 14 factors in terms of their importance for social work practitioners and 13 for social work education. Each factor was rated on a scale which indicated that one had little importance and six had great importance. T-tests for independent samples were conducted to determine if choice of scenario and educational status (BSW or MSW $s$ tudents) produced differences in the chosen factors.

Because of the small numbers of "Sweet Transformationalist" and "Sour Transformationalist" respondents, the following statistical analyses do not include them. Generally, the students who belleve that our society will undergo substantial changes (i.e., transformations), as a result of present trends, placed most of the factors into the low importance for social work classification. The "Sweet Transformationalism" respondents assigned intermediate importance to the management/planning technology cluster of factors. The "Sour Transformationalists" assigned no importance to this cluster, but rather saw intermediate importance in the need for social action skills. In contrast to the two dream scenarios, the "transformationalists" rejected such factors as social work values and university education as having much importance.

Social Work Practice: Table 3 presents the rank order of the 14 practice factors for the "American Dream" and "Unfulfilled Dream" scenarios (which were the most 
frequently chosen). While similarities exist in the means between scenarlos, signiflcant differences were found for seven factors. Involvement in social action at the state and local levels, but not the national level, and Improving social work's role as the "consclence of soclety" were significantly higher for respondents choosing the "Unfulfilled Dream;" whereas obtaining social work licensing, improving clinical skills, improving management skills and becoming more competent in using management information systems were significantly higher for respondents choosing the "American Dream." . Both groups belleved that social workers should develop more understanding of politics.

T-tests were conducted to determine if differences existed within scenarios by educational status. For the "American Dream," BSW and MSW students did not differ on any factor. However, BSW and MSW students who chose the "Unfulfilled Dream" differed on elght factors. The MSW students consistently assigned higher ratings to these factors: the need to become more politically involved at the state $(t=2.66)$, local $(t=2.66)$, and national $(t=3.21)$ levels; developing social planning skills ( $t=2.80)$; improving management skills ( $t=$ 2.33); creating new service delivery systems ( $t=$ $2.54)$; improving program evaluation $(t=4.98)$; and improving clinical skilis $(t=2.39) .3$

Further analysis of each of the 13 factors was conducted for respondents choosing the "American Dream" and Unfulfilled Dream" scenarios. T-tests for Independent samples were conducted to determine if BSW and MSW student ratings were significantly different. For those choosing the "American Dream" only one difference was found. MSW students rated the importance of developing a more specialized curriculum significantly higher than BSW students $(t=2.19)$. The mean score for this factor was 5.22 for MSW students, thereby making it the highest ranked factor. For those choosing the "Unfulfilled Dream," three variables were found which differentiated MSW and BSW students views: emphasis on management/planning skills, $(t=2.61)$; research/evaluation skills, $(t=2.46)$; and services to clients ( $t=$ 3.93).4 MSW students rated these factors as being more important than BSW students. 
Table 3

Implications for Social Work Practitioners

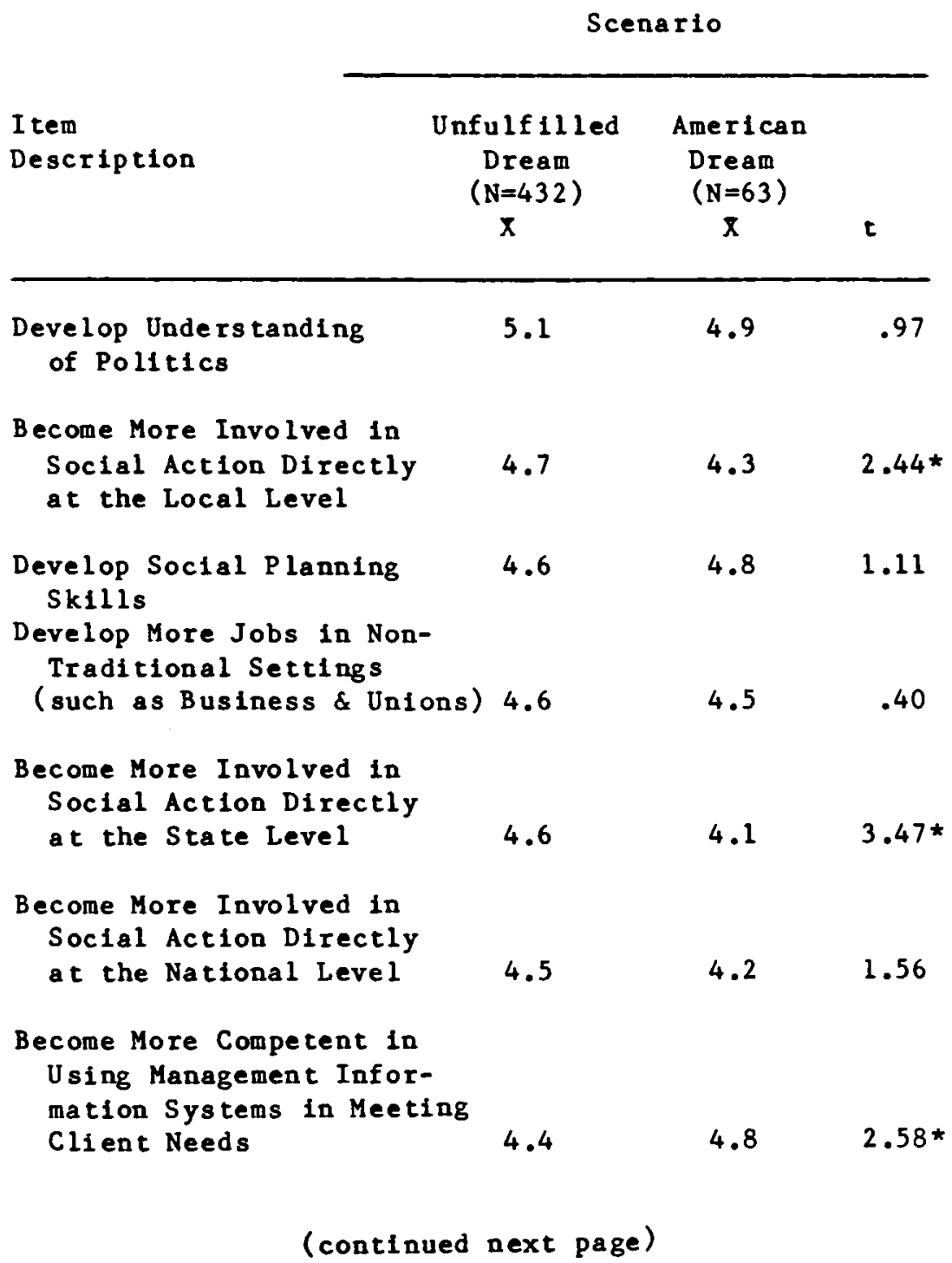


Table 3 continued

Implications for Social Work Practitioners

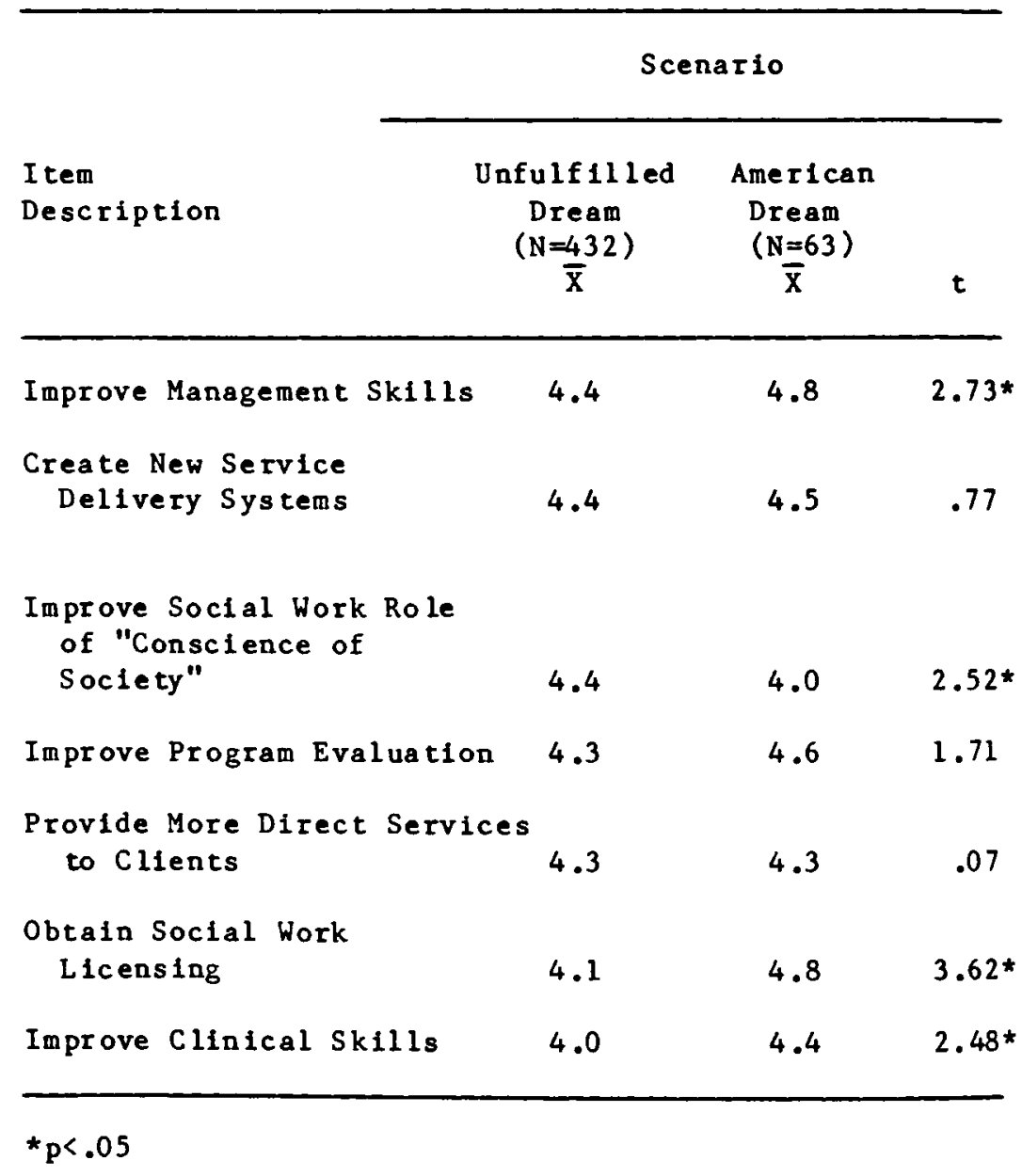


Social Work Education: Statistically significant differences were found that differentiated the "American Dream" and "Unfulfilled Dream" respondents" cholce on seven factors (see Table 4). Consistent with findings for practice implications, respondents choosing the "Unfulfilled Dream" belleved that more emphasis should be placed on social action, whereas respondents choosing the "American Dream" placed greater emphasis on management/planning skills, computer technology, and research/evaluation skills. Additionally, the latter respondents emphasized the need for a university education, the development of a more specialized curriculum, and focus on the middle class. Both groups belleved that education must place more emphasis on the development of leadership skills.

\section{DISCUSSION}

The finding that over 80 percent of respondents believe that the "Unfulfilled Dream" scenario is likely to occur supports a widely held belief that the "American Dream" has gone sour. Unemployment is the highest since the Depression. Minorities and women are especially vulnerable. Social work students have been confronted with the facts that positions in public and voluntary agencies are scarce, and in many instances, social workers have been reduced in-force. Many industries (e.g., steel, auto, construction) have laid of countless blue-collar employees and have shut down, leaving communities and states with public welfare burdens they are virtually unable to assume. National priorities have changed significantly, reversing a trend begun in the middle $1930^{\prime} \mathrm{s}$. Tax policies favoring the wealthy and declining public social welfare supports are just two items of the new agenda of the $1980^{\prime} \mathrm{s}$. The belief that the upper classes will benefit most and the lower classes will recelve little social justice, regardless of scenario chosen, reflects a pessimistic view on its dispensation.

The students who chose the two "dream" scenarios belleve that social workers need to gain the skills to work within bureaucracies. Furthermore, those students who chose "The Unfulfilled Dream" believe that social 
Table 4

Implications for Social Work Education

\section{Scenario}

\begin{tabular}{|c|c|c|c|}
\hline $\begin{array}{l}\text { Item } \\
\text { Description }\end{array}$ & $\begin{array}{l}\text { nfulf } 11 \text { led } \\
\text { Dream } \\
(\mathrm{N}=432) \\
x\end{array}$ & $\begin{array}{l}\text { Amer Ican } \\
\begin{array}{l}\text { Dream } \\
(N=63) \\
X\end{array}\end{array}$ & $t$ \\
\hline $\begin{array}{l}\text { Emphasis on } \\
\text { Leadership skills }\end{array}$ & 4.69 & 4.9 & 1.25 \\
\hline $\begin{array}{l}\text { Emphasis on Social } \\
\text { Action }\end{array}$ & 4.56 & 4.1 & $2.72 *$ \\
\hline $\begin{array}{l}\text { Emphasis on Manage- } \\
\text { ment/Planning Skills }\end{array}$ & 4.55 & 4.8 & $2.02 *$ \\
\hline $\begin{array}{l}\text { Need for Interdisci- } \\
\text { plinary Curriculum } \\
\text { (such as Political } \\
\text { Science \& Economics) }\end{array}$ & 4.49 & 4.4 & .55 \\
\hline $\begin{array}{l}\text { Need for University } \\
\text { Education }\end{array}$ & 4.33 & 5.2 & $5.29 *$ \\
\hline $\begin{array}{l}\text { Emphasis on Social } \\
\text { Work Values }\end{array}$ & 4.21 & 4.4 & .78 \\
\hline $\begin{array}{l}\text { Emphasis on Computer } \\
\text { Technology }\end{array}$ & 4.21 & 4.9 & 3.87 * \\
\hline
\end{tabular}


Table 4 continued

Implications for Social Work Education

\begin{tabular}{|c|c|c|c|}
\hline \multirow[b]{2}{*}{$\begin{array}{l}\text { Item } \\
\text { Description }\end{array}$} & \multicolumn{3}{|c|}{ Scenario } \\
\hline & $\begin{array}{l}\text { Unfulf } 11 \text { led } \\
\text { Dream } \\
\left(\mathrm{N}=\frac{432}{\bar{X}}\right.\end{array}$ & $\begin{array}{c}\text { American } \\
\text { Dream } \\
\left(N=\frac{63}{x}\right)\end{array}$ & $\mathbf{t}$ \\
\hline $\begin{array}{l}\text { Develop More Special } \\
\text { ized Curriculum }\end{array}$ & 4.18 & 4.9 & 3.76 * \\
\hline $\begin{array}{c}\text { Emphasis on Research } \\
\text { Evaluation Skills }\end{array}$ & 4.11 & 4.7 & $3.66 *$ \\
\hline $\begin{array}{l}\text { Emphasis on Services } \\
\text { to Clients }\end{array}$ & 4.06 & 4.3 & 1.12 \\
\hline Focus on the Poor & 3.90 & 3.7 & 1.09 \\
\hline $\begin{array}{l}\text { Focus on the Middle } \\
\text { Class }\end{array}$ & 3.77 & 4.1 & $1.96 *$ \\
\hline $\begin{array}{l}\text { Maintain Generalist } \\
\text { Curriculum }\end{array}$ & 3.66 & 3.5 & 1.15 \\
\hline
\end{tabular}


workers will need to develop greater social action skills to seek professional and client goals. "The American Dream" respondents relegated direct services to cllents to the medium importance category, but "The Unfulfilled Dream" respondents placed it into the lowest category. This surprising finding may conflict with the reality of agency-based direct service practice of most social workers.

The "American Dream" and "Unfulfilled Dream" respondents in this study saw a need for expanded education on leadership, social action, technology and management. Presumably, know ledge in these areas will make them more marketable in the fierce competition with other "human services" and business-trained personnel. This observation applies at both the MSW and BSW levels. Certainly enhancing the students' leadership skills (which mostly concern human relationships) and technology/management skills will provide a stronger profession than at present.

Faculty in BSW and MSW programs should consider further development of their curricula to enhance their students' leadership skills. Although a separate course could be developed, because of lack of resources, many programs will have to enhance such skills within their present professional foundation courses. Making presentations before classes, group simulations and writing papers on leadership, developed in a sequential fashion, could meet this goal.

Further, students could be encouraged to take leadership positions on the campus and in the community. In a similar fashion computer technology could be learned through separate courses or integrated courses. Management training will require separate courses. Social action courses should recelve enhanced visibility. This education in social action is applicable at the BSW, as well as the MSW, level. This is not to say, however, that the focus on social work values should be decreased.

In advocating that social workers become active participants, rather than bystanders in shaping the future, Minahan developed a list of potential 
activities (Minahan, 1981). These Included teaching clients survival and self-help skills, making bureaucracies responsive to people, incorporating new technology (such as computers) Into the profession, and becoming active in new services development and social advocacy. The activities on the list match well with this study's list of implications for leadership, social action and management/planning in social work practice and education, thereby providing support for their Importance.. Furthermore, the findings support the predictions of David, Briar and Rothman, which were previously discussed.

Social work is sufficiently mature as a profession to move away from strictly "genius forecasting" to more sophisticated prediction techniques. The work of NASW's Professional Futures Commission is to be commended. The use of more contemporary future prediction techniques should yield results which will help to further strengthen our profession and services for our clients.

\section{NOTES}

1. The social work programs in the following universities/ colleges participated in the study:

Florida State University Utah State University Florida International Uni. Uni. of Northern Iowa Uni. of Tenn.-Knoxville Clark College, Iowa Un1. of Kentucky

Eastern Kentucky Uni. Western Kentucky Uni. Murray State Uni., KY University of Houston Kentucky State University University of Iowa Uni. of Wis.-Eau Claire Uni. of Wisc.-Superior Wright State Uni., Ohio Manka to State Uni., MN Simpson College, Iowa

2. Copyright 1981 , National Association of Social Workers, Inc. Reprinted with permission, from Social Work, Vol. 26, No. 5. (September 1981), pp. 367372, excerpts.

3. $p<.05$; df varied from $422-430$. 
4. $p<.05 ;$ df varied from 426-429.

\section{REFERENCES}

Abels, Paul

1975 "Terra Incognita: The future of the profession." Social Work, 20 (January): 25-28.

Beck, Bertram

1981 "Social work's future: triumph or disaster." Social Work, 26 (September): 367-372.

Boehm, Werner

1976 "Social work education: issues and problems in the light of recent developments." Journal of Education for Social Work, 12 (Winter): 20-27.

Briar, Scote

1974 "The future of social work: an introduction." Soc1al Work, 19 (S ep tember): 514-518.

Council on Social Work Education

1982 "Successful 1982 annual program meeting concluded." Social Work Education Reporter, 30 (May): 3,6 .

David, Hen ry

1967 "Education for the professions: common issues, problems, and prospects." Journal of Education for Social Work, 3 (Spring): 5-12.

Dolgoff, Ralph and Donald Feldstein

1984 "Social trends affecting social welfare." Understanding Social Welfare ( 2 nd ed.). New York: Longman, Inc.

Gardner, John

1966 "Remarks." Journal of Education for Social Work, 2 (spring): 5-9. 
Issues in Baccalaureate Soclal Work Education and Practice as We Look to the $1980 \mathrm{~s}$.

1979 Conference convened by the Lois and Samuel Silberman Fund, April 22-23 in New York City.

Jones, Thomas

1980 Options for the Future: A Comparative AnalYork: Praeger Publishers.

Kendal 1 , Katherine

1967 "To fathom the future." Journal of Education for Social Work, 3 (Spring): 21-28.

Lowy, Louls

1968 "Whither social work education amid social change?" Journal of Education for Social Work, 4 (spring): $31-36$.

Mefnert, Roland

1973 "Futures forecasting." Social Work, 18 (November): 48-51.

Minahan, Anne

1981 "Soclal workers and the future." (editorial). Social Work, 26 (S ep tember): 363-364.

Council on Social Work Education

1982 "Minutes." House of Delegates Meeting, March 10-11, in New York City.

Pins, Arnulf

1967 "Current realities and future opportunities for soclal work education." Journal of Education for Social Work, 3 (Spring): 51-59.

Reichert, Kurt

1970 "Current developments and trends in social work education in the United States." Journal of Education for Soctal Work, 6 (Fall): $39-50$. 
Rothman, Jack

1979 "Macro social work in a tightening economy." Social Work, 24 (July): 274-281.

Rubin, Allen

1982 Statistics on Social Work Education in the United States: 1981. New York: Councll on Social Work Education.

Washing ton, $R$, 0 .

1978 "Social work in the future and implications for soclal work education." California

Soclologist, 1 (Summer): 193-204. 